\title{
TINGKAT PENGUASAN SELF REGULATED LEARNING SKILLS PADA MAHASISWA JURUSAN ADMINISTRASI NIAGA
}

\author{
Wahyudi Utomo ${ }^{1 \bowtie}$, Azwar $^{2}$ \\ ${ }^{1,2}$ Administrasi Niaga, Politeknik Negeri Jakarta, Jl. Prof. DR. G.A. Siwabessy, Kukusan, Kecamatan Beji, \\ Kota Depok, Jawa Barat 16424 \\ e-mail." wahyudi.utomo@bisnis.pnj.ac.id, ${ }^{2}$ azwar@bisnis.pnj.ac.id
}

\begin{abstract}
This research is a survey research, with a quantitative approach. This study aims to see the differences in self-regulated learning skills in students who participate in organizations and students who do not participate in organizations in the Department of Business Administration. The population in this study were students who participated in the formal organization at the Jakarta State Polytechnic. The sampling technique used in this study was non-probability sampling, namely purposive sampling. The number of samples taken was 60 students, 30 students who participated in the Organization and 30 students who did not participate in the Organization, either male or female. Meanwhile, the data collection technique uses a self-regulated learning scale with a rating system using a Likert scale. The primary data collected were analyzed using the SPSS computer program. The results showed that there was no difference between students who participated in the organization and those who did not participate in the organization, with the mean empiric for students who participated in student organizations of (150.70) and students who did not participate in organizational activities the same number of student affairs (147.63) are in the high category.
\end{abstract}

Keywords: Self Regulated Learning Skills, Formal Student Organization

\begin{abstract}
Abstrak
Penelitian ini merupakan penelitian survei, dengan pendekatan kuantitatif. Penelitian ini bertujuan untuk melihat perbedaan self regulated learning skills pada mahasiswa yang mengikuti organisasi kemahasiswaan dan mahasiswa yang tidak mengikuti organisasi kemahasiswaan di Jurusan Administrasi Niaga. Populasi dalam penelitian ini adalah mahasiswa Jurusan Administrasi Niaga di Politeknik Negeri Jakarta. Teknik sampling yang digunakan dalam penelitian ini adalah sampling nonprobabilitas yaitu Purposive Sampling. Jumlah sampel yang diambil sebanyak 60 mahasiswa, 30 mahasiswa yang mengikuti organisasi kemahasiswaan dan 30 mahasiswa yang tidak mengikuti organisasi kemahasiswaan baik mahasiswa laki-laki atau perempuan. Sedangkan teknik pengumpulan data menggunakan skala self regulated learning dengan sistem penilaian menggunakan skala Likert. Data primer yang terkumpul dianalisis dengan menggunakan bantuan program komputer SPSS. Hasil Penelitian menunjukan tidak terdapat perbedaan antara mahasiswa yang mengikuti organisasi dan yang tidak mengikuti organisasi, dengan mean empiric pada mahasiswa yang mengkuti organisasi kemahasiswaan sebesar $(150,70)$ dan mahasiswa yang tidak mengikuti kegiatan organisasi kemahasiswaan sebesar $(147,63)$, sama sama berada pada kategori tinggi.
\end{abstract}

Kata Kunci: Self Regulated Learning Skills, Organisasi Formal Kemahasiswaan

\section{Pendahuluan}

\section{Latar Belakang}

Self regulated learning adalah kemampuan siswamenetapkan tujuan untuk proses belajarnya dan berusaha untuk memonitor, meregulasi, dan mengontrol kognisi, motivasi, dan perilaku, yang kemudian semuanya diarahkan dan didorong oleh tujuan dan disesuaikan dengan konteks lingkungan, (Wolters, 
Pintrich, \& Karabenick, 2003). Sedangkan menurut Zimmerman (dalam Heru Basuki, 2005) siswa dikatakan telah menggunakan SLR (self-regulated learning) bila siswa tersebut memiliki strategi untuk mengaktifkan metakognisi, motivasi dan tingkah laku dalam proses belajar mereka sendiri. Pengaruh lingkungan juga lebih kuat dari pada pengaruh personal atau tingkah laku.

Menurut Corno dan Madinach (dalam Halilintar, 2010) mendefinisikan self regulated learning sebagai suatu usaha yang dilakukan individu untuk menyelesaikan tugas akademik dengan menggunakan cara-cara relevan dan tidak terbatas hanya pada materi pelajaran serta membuat perencanaan dan pengawasan pada proses kognitif dan afektifnya. Sedangkan menurut Yoenanto (2010) self regulated learning adalah mengacu pada kemampuan dari siswa untuk memahami dan mengontrol belajarnya, dimana siswa memerlukan untuk mengontrol belajarnya melalui keyakinan akan motivasi yang produktif dan menggunakan strategi belajar kognitif. Siswa yang melakukan self regulation dalam belajar, mereka secara sistematis mengatur perilaku dan kognisinya dengan memperhatikan aturan yang dibuat sendiri, mengontrol berjalannya suatu proses belajar dan mengintegrasikan pengetahuan, melatih untuk mengingat informasi yang diperoleh, serta mengembangkan dan mempertahankan nilai-nilai positif belajarnya (Akhmadi, 2012).

\section{Rumusan Masalah}

Berlatar belakang masalah, secara spesifik dirumuskan permasalahan yang akan diteliti yaitu, apakah terdapat perbedaaan kemampuan self regulated learning skill pada mahasiswa yang mengikuti organisasi kemahasiswaan dan yang tidak mengkuti organisasi kemahasiswaan.

\section{Tujuan Penelitian}

Berdasarkan rumusan masalah, tujuan penelitian ini yaitu untuk menganalisis dan mendeskripsikan tingkat perbedaaan self regulated learning skill pada mahasiswa yang mengikuti organisasi dan yang tidak mengkuti organisasi kemahasiswaan.

\section{Tinjauan Pustaka}

1. Pengertian Self Regulated Learning Pengaturan diri tingkah laku (self-regulation behavior) mencangkup berbagai bidang, diantaranya pengaturan diri dalam belajar disekolah (self-regulation academic learning) selanjutnya disebut self-regulated learning dan disingkat SLR (Heru Basuki, 2005). Siswa dikatakan telah menggunakan SLR (self-regulated learning) bila siswa tersebut memiliki strategi untuk mengaktifkan metakognisi, motivasi dan tingkah laku dalam proses belajar mereka sendiri (Zimmerman dalam Heru Basuki, 2005). Menurut Yoenanto (2010) self regulated learning adalah mengacu pada kemampuan dari siswa untuk memahami dan mengontrol belajarnya, dimana siswa memerlukan untuk mengontrol belajarnya melalui keyakinan akan motivasi yang produktif dan menggunakan strategi belajar kognitif.

Menurut Munjirin dan Shidiq (2008), self regulated learning adalah kemampuan untuk mengatur diri dalam belajar dengan mengikutsertakan kemampuan metakognisi, kemampuan perencanaan, pengorganisasian, menginstruksi diri, memonitor dan melakukan evaluasi dalam aktivitas 
belajar, motivasi adalah sebagai dorongan diri (self drive) mencangkup persepsi terhadap efikasi diri, menyeleksi dan memanfaatkan lingkungan maupun menciptakan lingkungan yang menentukan aktivitas belajar.

\section{Aspek-aspek Self Regulated \\ Learning}

Struktur wawancara yang digunakan untuk mengukur strategi yang digunakan oleh siswa dalam belajar yang disusun oleh Zimmerman dan Martinez-Pons 1986 (dalam Heru Basuki 2005) yaitu sebagai berikut:

a. Evaluasi diri (self-evaluation), yaitu pernyataan mengindikasikan siswa untuk menilai kualitas tugas yang telah diselesaikan, pemahaman terhadap lingkup kerja, atau usaha dalam kaitan dengan tuntutan tugas.

b. Mengatur dan mengubah (organizing and transforming) yaitu pernyataan yang mengindikasikan keinginan siswa baik secara terus terang atau diam-diam dalam mengatur ulang materi petunjuk untuk mengembangkan poses belajar.

c. Menetapkan tujuan dan perencanaan (goal setting and planning), yaitu pernyataan yang mengindikasikan perencanaan siswa untuk mencapai tujuan pendidikan atau sub tujuan dan rencana untuk mengurutkan prioritas, menentukan waktu dan menyelesaikan rencana semua aktivitas yang terkait dengan tujuan tersebut.

d. Mencari informasi (seeking information) yaitu pertanyaan yang mengindikasikan upaya untuk mencari informasi yang berkaitan dengan tugas dari sumber-sumber lain saat mengerjakan tugas.

e. Menyimpan catatan dan memantau (keeping records and monitoring), yaitu pertanyaan yang mengindikasikan upaya siswa untuk mencatat hal-hal penting dalam pelajaran.

f. Mengatur lingkungan (environment structuring), yaitu pertanyaan yang mengindikasikan upaya siswa untuk mengatur lingkungan belajar agar membuat belajar lebih nyaman dengan mengatur lingkungan fisik maupun psikologis.

g. Konsekuensi diri (self-consequences), yaitu pernyataan yang mengindikasikan upaya siswa dalam mempersiapkan atau membayangkan yang mengindikasikan upaya siswa dalam mempersiapkan atau membayangkan dan melaksanakan ganjaran atau hukuman untuk kesuksesan dan kegagalan.

h. Mengulang dan mengingat (rehearsing and memorizing), yaitu pertanyaan yang mengindikasikan upaya siswa untuk mengingat-ingat materi bidang studi dengan diam atau dengan suara keras.

i. Mencari dukungan sosial (seeking social assistance), yaitu pertanyaan mengindikasikan upaya siswa untuk mencapai bantuan dari rekan-rekan sebaya dari guru dan dari orang dewasa.

j. Memeriksa catatan (reviewing records), yaitu pertanyaan yang mengindikasikan upaya siswa untuk membaca kembali catatan ulangan atau buku teks.

k. Lain-lain (other), yaitu pernyataan yang mengindikasikan tingkah laku belajar yang dicontohkan oleh orang lain seperti guru dan orang tua, pernyatan keinginan yang kuat atau mengekspresiakan secara lisan atau secara tulisan hal-hal yang belum jelas.

\section{Metode Penelitian}

Jenis penelitian yang digunakan adalah metode penelitian survei kuantitatif yaitu yang bertumpu pada hypothetico-deductive method dengan menggunakan analisis data yaitu statistic dekriptif. Uji hipotesis menggunakan analisis regresi linier 
sederhana untuk mengetahui kontribusi masing masing variable bebas terhadap variable terikat secara individual. Uji hipotesis dilakukan dengan menggunakan SPSS berdasarkan pada nilai signifikansi.

\section{Teknik Pengumpulan Data}

Untuk mendapatkan data-data dan sejumlah informasi yang akurat, maka diperlukan teknik pengumpulan data, yaitu

1) Angket digunakan untuk menjaring data primer dan diedarkan langsung pada mahasiswa perguruan tinggi yang menjadi sampel penelitian ini. Pilihan jawaban angket tersebut bersifat tertutup.

2) Teknik sampling yang digunakan dalam penelitian ini adalah sampling nonprobabilitas yaitu Purposive Sampling

3) Subjek penelitian ini adalah mahasiswa Jurusan Administrasi Niaga yang terpilih sebagai responden

\section{Pembahasan}

\section{Pelaksanaan Penelitian}

Penelitian ini menggunakan metode try out terpakai, yakni dimana data yang diperoleh dengan satu kali pengambilan data (penyebaran angket) yang digunakan untuk menguji hipotesis dalam penelitian. Hal ini dilakukan karena data yang didapat untuk melakukan uji hipotesis memiliki kesamaan data dengan uji validitas dan realibilitas dan juga karena adanya keterbatasan waktu responden untuk mengisi kuesioner agar tidak menggangu waktu belajar para mahasiswa saat dikampus. Proses pengambilan data dilakukan di Jurusan Administrasi Niaga pada tanggal 12
September 2019. Pemilihan responden dengan cara menyebarkan kuesioner kepada Mahasiswa/i di Jurusan Administrasi Niaga. Jumlah mahasiswa yang diperoleh sebanyak 60 siswa, yang terdiri dari 30 mahasiswa yang mengikuti organisasi kemahasiswaan dan 30 mahasiswa yang tidak mengikuti organisasi kemahasiswaan baik perempuan atau laki-laki. Dari kuesioner yang didapat, seluruhnya layak dan memenuhi syarat untuk dianalisis. Adapun jumlah keseluruhan responden yang berhasil didapatkan pada try out terpakai tersebut sebanyak 60 mahasiswa.

\section{Analisa Hasil}

Hasil analisa perbedaan self regulated learning pada mahasiswa yang mengikuti Organisasi dengan yang tidak mengikuti Organisasi pada mahasiswa Jurusan Administrasi Niaga menghasilkan nilai 0,539 dengan taraf signifikansi sebesar 0,592 ( $\mathrm{p}>0,05)$. Berdasarkan hasil penelitian diketahui bahwa hipotesis yang telah dirumuskan ditolak, yang artinya tidak terdapat perbedaan antara self regulated learning pada mahasiswa yang mengikuti Organisasi dan mahasiswa yang tidak mengikuti Organisasi yang sangat signifikan pada mahasiswa/i Jurusan Administrasi Niaga.

Hal tersebut menunjukkan bahwa siswa yang mengikuti Organisasi dan tidak mengikuti Organisasi sama-sama memiliki self regulated learning. Karena baik mahasiswa yang mengikuti Organisasi atau tidak mengikuti Organisasi memiliki tanggung jawab agar dapat mengatur diri sendiri untuk mengontrol proses belajar dan keterampilan mereka dalam belajar agar hasil yang diperoleh lebih baik. Menurut Yoenanto (2010), self 
regulated learning mengacu pada kemampuan diri mahasiswa untuk memahami dan mengontrol belajarnya, dimana siswa memerlukan untuk mengontrol belajarnya melalui keyakinan akan motivasi yang produktif dan menggunakan startegi belajar yang kognitif.

Motivasi dan kepercayaan diri juga mempengaruhi bagaimana, dan mengapa siswa belajar dengan baik. Mahasiswa yang memiliki motivasi tinggi cenderung menentukan tujuan belajar yang lebih tinggi pada dirinya, mendesain kegiatan-kegiatan belajar atas inisiatif sendiri, mengembangkan observasi diri, dan mengembangkan evaluasi diri dalam belajar. Hal ini didukung hasil dari penelitian yang menemukan bahwa siswa yang memiliki motivasi dan minat tinggi pada materi kuliah menggunakan lebih banyak strategi self-regulated learning, daripada mahasiswa yang memiliki motivasi dan minat rendah pada materi kuliah (Suminarti dan Fatimah, 2013).

Mahasiswa yang memiliki tanggung jawab diluar pelajaran seperti mengikuti Organisasi dan tidak mengikuti Organisasi dituntut untuk dapat mandiri serta mampu meningkatkan motivasi belajar mereka. Kegiatan Organisasi dapat menumbuhakan sikap bertanggung jawab, sikap tanggung jawab harus dimiliki oleh setiap anggota Organisasi baik sebagai pengurus Organisasi maupun sebagai mahasiswa yang mempunyai tanggung jawab menjalankan roda organisasi dan belajar (Irawan, 2011).

Faktor yang mempengaruhi self regulated learning juga dapat dilihat dari ; proses dari dalam diri, dimana mahasiswa mengorganisasikan tindakannya untuk mencapai tujuan mereka dalam memproses suatu informasi baru, tingkah laku mahasiswa dimana mahasiswa memantau, membandingkan secara sistematis tujuan akademik yang telah mereka tetapkan sendiri, dan terakhir yaitu lingkungan mahasiswa dimana lingkungan sosial dan pengalaman yang didapat oleh mahasiswa juga dapat pembentukan tingkah laku mahasiswa. Hal ini sependapat dengan Zimmerman (dalam Heru Basuki 2005) seorang mahasiswa dapat dikatakan sebagai self regulated lerner apabila mahasiswa tersebut memiliki strategi untuk mengaktifkan metakognisi, motivasi dan tingkah laku dalam proses belajar mereka sendiri.

Pada mahasiswa baik yang mengikuti Organisasi maupun tidak mengikuti Organisasi memiliki self regulated learning yang tinggi dilihat dari hasil penelitian, didapatkan mean empirik self regulated learning pada mahasiswa yang mengikuti Organisasi sebesar $(150,70)$ dan mahasiswa yang tidak mengikuti Organisasi sebesar $(147,63)$ berada pada katagori tinggi. Ini menunjukan self regulated learning pada mahasiswa/i Jurusan Administrasi Niaga baik yang mengikuti Organisasi atau tidak mengikuti Organisasi berada pada tingkatan tinggi. Menurut hasil penelitian Sudjana (2003), semakin tinggi skor pada self regulated learning maka akan semakin sering mahasiswa menerapkan dan menggunakan strategi-strategi self regulated learning dalam belajarnya dan akhirnya hal ini akan memberikan dampak langsung terhadap belajarnya. Dan menurut Sumarmo (2009), individu yang memiliki self regulated learning yang tinggi cenderung belajar lebih baik, mampu memantau, mengevaluasi, dan 
mengatur belajarnya secara efektif; menghemat waktu dalam menyelesaikan tugasnya; mengatur belajar dan waktu secara efisien, dan memperoleh skor yang tinggi.

Para siswa secara tidak langsung dituntut untuk memiliki tanggung jawab dalam proses belajar mereka. Mahasiswa yang telah menggunakan self regulated learning dalam proses belajarnya memulai dan mengarahkan usahanya untuk memperoleh pengetahuan dan keterampilan ketimbang bergantung pada guru, orang tua atau agen pembelajaran yang lain (Heru Basuki,2005). Sehingga tidak dipungkiri baik mahasiswa yang mengikuti Organisasi dan tidak mengikuti Organisasi juga memiliki self regulated learnig dalam proses belajar.

\section{Kesimpulan}

Berdasarkan hasil pengumpulan dan analisis data yang telah dilakukan, maka dapat diketahui bahwa tidak terdapat perbedaan self regulated learning pada mahasiswa yang mengikuti Organisasi Kemahasiswaan dan tidak mengikuti Organisasi Kemahasiswa pada mahasiswa Jurusan Administrasi Niaga. Mahasiswa yang mengikuti Organisasi Kemahasiswaan dan tidak mengikuti Organisasi Kemahasiswaan memiliki self regulated learning tinggi, dengan mean emprik pada mahasiswa yang mengikuti Organisasi sebesar $(150,70)$ dan mahasiswa yang tidak mengikuti Organisasi sebesar $(147,63)$ sama-sama berada pada katagori tinggi. Mahasiswa memiliki self regulated learning untuk membantu mereka agar dapat mengontrol proses belajar dengan hasil yang lebih baik.

\section{Saran}

Berdasarkan hasil penelitian yang dilakukan, maka saran-saran yang dapat diberikan adalah sebagai berikut:

\section{Bagi Subjek Penelitian}

Diaharapkan agar dapat tetap mempertahankan sikap tanggung jawab kepada diri sendiri dalam proses belajar mereka, dan tetap menggunakan self regulated learning agar dalam proses belajarnya dapat menghasilkan hasil yang jauh lebih baik lagi.

\section{Bagi Pendidik dan Institusi}

Hasil penelitian ini menunjukan bahwa tidak terdapat perbedaan self regulated learning pada mahasiswa yang mengikuti Organisasi Kemahasiswaan dan tidak mengikuti Organisasi pada mahasiswa Jurusan Administrasi Niaga, maka disarankan agar jurusan dan dosen untuk dapat mempertahankan proses belajar mengajar yang baik kepada para mahasiswanya dan lebih mengarahkan para mahasiswa agar mereka tetap mempertahankan sikap dan tanggung jawab mereka sebagai peserta didik.

\section{Bagi Peneliti Selanjutnya}

Agar dapat melakukan penelitian lebih mendalam atau mencoba menggali lebih dalam lagi tentang self regulated learning pada mahasiswa, dengan memperbarui subjek, metode serta variable yang berbeda dan memberikan masukan-masukan yang berguna bagi pengembangan ilmu pengatahuan selanjutnya. 


\section{Daftar Pustaka}

Halilintar, M. (2010). Self regulated learning pada anak home schooling tunggal (Skripsi). Depok: Universitas Gunadarma.

Heru, B. A. (2005). Kreativitas, keberbakatan intelektual dan faktor-faktor pendukung dalam pengembangannya. Depok: Universitas Gunadarma.

Irawan, S. (2011). Pengembangan kepemimpinan siswa melalui kegiatan osis di SMA 4 depok (Skripsi). Jakarta: Universitas Syarif Hidayatullah.

Sudjana. (2003). Hubungan antara self regulated learning dengan prestasi belajar fisika siswa kelas 2 SMU Negeri 5 Jakarta (Skripsi). Depok: Universitas Indosnesia.

Sumarmo, U. (2009). Kemandirian belajar (apa, mengapa, dan bagaimana dikembangkan pada peserta didik). Retrieved september 30, 2013, from http://math.sps.upi.edu/?p=61

Suminarti, F., \& Fatimah, S. (2013). Self-regulated learning (SLR) dalam meningkatkan prestasi akademik pada mahasiswa. Jurnal ilmiah psikologi terapan , 01, 147-149.

Wolters, C., Pintrich, P., \& Karabenick, S. (2003). Assesing academic self-regulated learning. Conference on Indicators of Positive Development: Child Trends.

Yoenanto, N. H. (2010). Hubungan antara self-regulated learning dengan self-efficacy pada siswa akselerasi sekolah menengah pertama di jawa timur. Jurnal , 12, 90-93.

Zimmerman, B. J., \& Schunk, D. H. (1989). Self regulated leraning and academic achievement: Theory, research and practice. New York: Springer-Verlag. 